\title{
Countermeasures Study on Industrial Structure Optimization in Tongliang District of Chongqing

\author{
Ping Ning ${ }^{1, a^{*}}$, Peiyin Zhong ${ }^{1, b}$, and Qi Jiang ${ }^{2, c}$
}

${ }^{1}$ Automotive engineering faculty, Chongqing creation vocational College, Yongchuan, Chongqing, China

${ }^{2}$ Cultural radio and TV \& tourism bureau in Longchang of Sichuan Provence, Longchang, Sichuan, China

anp98783@163.com, b13996414404@139.com, c229918036@qq.com

Keywords: Industrial structure, Optimization, Countermeasures.

\begin{abstract}
Aiming at the demand of industrial structure optimization in Tongliang district of Chongqing from the innovation-driven perspective, through investigation and literature search, from 2016, 2017 and 2018 respectively, the present situation of industrial structure in the district is analyzed, on this basis, the characteristics of existing industrial structure in the district are discussed, including the advantages, shortages and the industry comparison with surrounding areas \& counties, based on an innovation-driven strategy, the countermeasure on industrial structure optimization in Tongliang district is put forward.
\end{abstract}

\section{重庆市铜梁区产业结构优化的对策研究}

宁萍 $1, a,{ }^{*}$, 钟培尹 ${ }^{1, b}$, 蒋淇 $2, c$

重庆科创职业学院汽车工程系, 重庆永川, 中国

2 四川省隆昌市文化广播电视和旅游局, 隆昌, 四川, 中国

anp98783@163.com, b13996414404@139.com, c229918036@qq.com

关键词：产业结构；优化；对策

中文摘要. 针对创新驱动视域下重庆市铜梁区产业结构优化的需求, 通过调研和文献查询, 分别从2016年、2017年及2018年三个年份，分析了铜梁区产业结构的现状; 在此基础上，讨 论了铜梁区现有产业结构的特性, 包括优势、短板及与周边区县的产业比较, 提出基于创新 驱动战略的铜梁区产业结构优化的对策。

\section{1. 引言}

产业结构系指某一产业在国民经济中的占比，如农业、工业和服务业在国民经济中所占 的比重。一方面, 产业结构的变化能够为某些行业带来难得的市场机会, 在另一方面产业结 构的变化也会对其他行业造成生存的威胁。通常在社会经济发展的过程中，服务业的重要性 会与日俱增，服务业的比重会日益增大，服务业从业者将会得到较多的市场机会 ${ }^{[1]}$ 。铜梁区 产业结构优化的对策分析, 对铜梁区基于创新驱动战略的产业结构发展具有重要的现实意义。 


\section{2. 铜梁区产业结构的现状}

建国初期, 铜梁是个典型的农业县, 改革开放以来, 铜梁的产业结构逐渐趋于合理, 并 向优化和升级方向发展。目前, 铜梁区的产业布局为六大产业集群, 如图1所示。

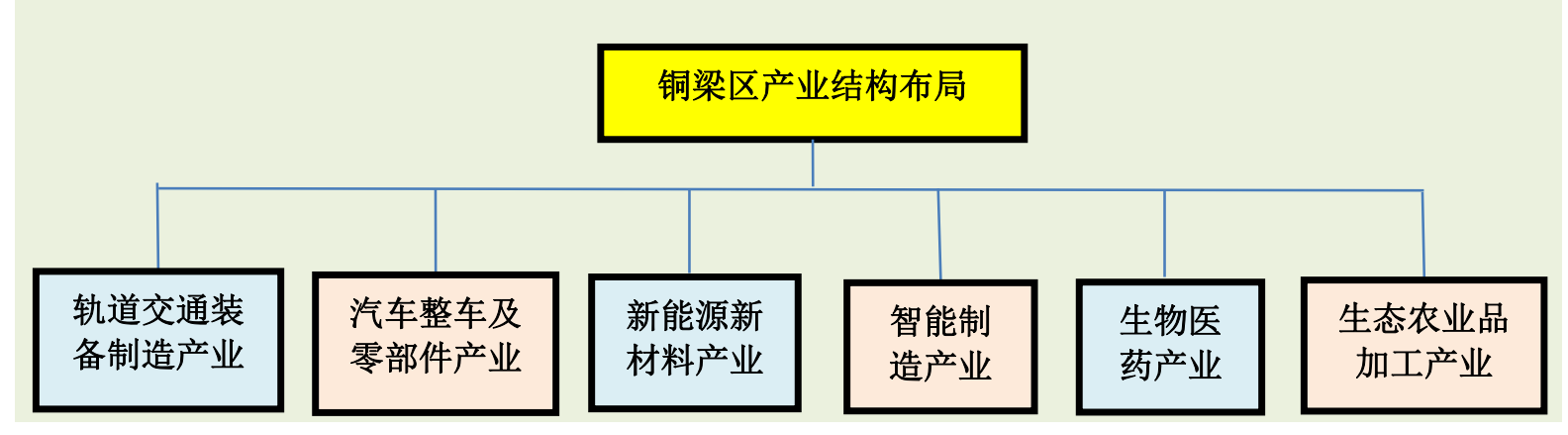

图 1. 铜梁区六大产业集群示意图

\section{1 铜梁区产业发展的基础条件}

铜梁区位于长江上游、重庆西北部及重庆国家中心城市的核心地带; 南北长约 $62 \mathrm{kM}$, 东

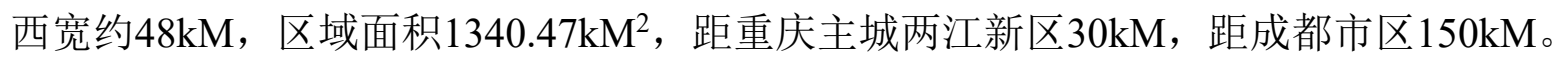

铜梁区现有交通运输用地 2657 公顷，水域及水利设施用地 5562 公顷，与 2016 年相比， 大致持平。铜梁全区多年平均拥有过境水资源 197.12 亿 $\mathrm{m} 3$, 实际年利用量为 2.12 亿 $\mathrm{m} 3$, 仅 为每年外来过境水总量的 $1.08 \%$ ，开发利用率较低。

铜梁区具备产业发展的区位优势、水文资源、交通设施、土地资源等基础条件。

\subsection{6 年铜梁区的产业结构}

2016 年铜梁全区实现生产总值 341.57 亿元, 增长 $11.1 \%$ 。

第一、二、三产业 2016 年增加值及占比如表 1 所示。

表 1 铜梁区 2016 年各产业增加值变化情况

\begin{tabular}{|c|c|c|c|}
\hline 2016年 & 实现增加值 & 比上年增长 & 产业占比 \\
\hline 第1产业 & 41.42 亿元 & $5.1 \%$ & 12.1 \\
\hline 第2产业 & 201.26 亿元 & $12.3 \%$ & 58.9 \\
\hline 第3产业 & 98.89 亿元 & $11.1 \%$ & 29.0 \\
\hline
\end{tabular}

从表 1 可见: 三次产业结构占比为 12.1：58.9: 29.0。

\subsection{7 年铜梁区的产业结构}

2017 年，铜梁全区实现生产总值 381.8 亿元、增长 $9.8 \%$ ；工业增加值 180.3 亿元、增长 $10.5 \%$ ；固定资产投资 599.2 亿元、增长 $5.3 \%$ ；城镇化率提高到 $54.8 \%$ 。

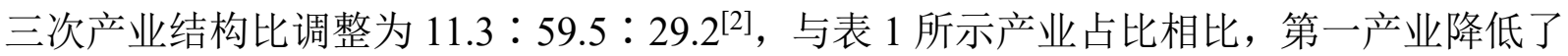
0.8 个百分点; 第二产业增加了 0.6 个百分点; 第三产业增加了 0.2 个百分点。

\subsection{8 年铜梁区的产业结构}

2018 年完成工业投资 88 亿元，增长 $15 \%$ ，规上工业实现总产值 495 亿元，增长 $11.6 \%$ 。 2018 年全年地区生产总值增长 $9.6 \%$, 工业增加值增长 $9.1 \%, 2018$ 年实现农业总产值 63.85 亿元、增长 4.9\%。2018 年铜梁区战略性新兴产业产值增长 $20.3 \%$, 高新技术产业产值增长 $17.6 \%$, 数字经济产业产值增长 $33.6 \%$, 对规上工业产值增长贡献率分别达 $18.1 \%$ 、35.3\%和 43.8\%; 工业用电量增长 $11.2 \%$, 用气量增长 44\%; 三次产业结构比由 11.3： 59.5：29.2 调整 为 9.4: $55.5: 35.1^{[3]}$ 。

铜梁区 2016 年、2018 年三类产业占比分析如图 2、图 3 所示。 


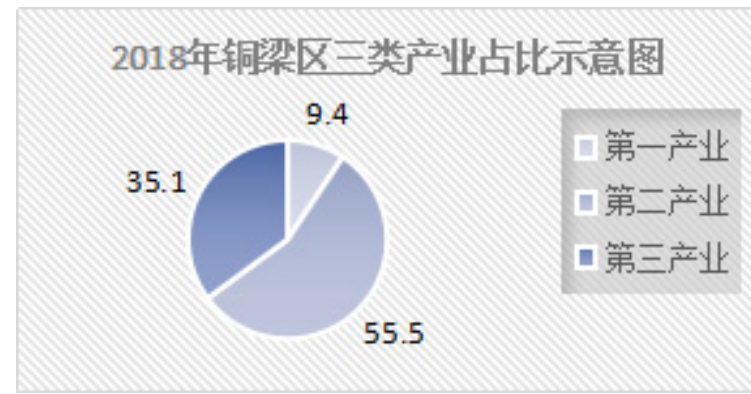

图2 2016年铜梁三类产业占比示意图

\section{6年铜梁区二类产业占比示意图}

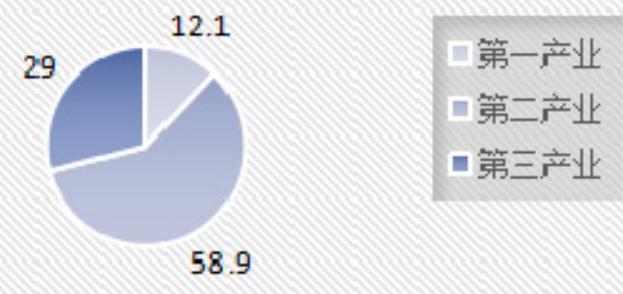

图3 2018年铜梁三类产业占比示意图

从图 2、图 3 不同产业占比可见, 2016 年以来, 铜梁区第一产业的比重从 12.1 降到 9.4, 降低了 2.7 个百分点; 第二产业比重从 58.9 降到 55.5 , 降低了 3.4 个百分点; 第三产业比重 从 29 上升到了 35.1 , 上升了 6.1 个百分点; 即铜梁区 2018 年第一、第二产业占比下降, 而 第三产业占比明显增长。

\section{3. 铜梁区产业结构的特性}

\section{1 产业结构发展的优势}

\subsection{1 党政高度重视}

铜梁区委、区政府对辖区产业结构的优化高度重视, 产业结构优化正处于全面落实中央、 重庆市委改革部署, 落实习近平总书记对重庆提出的“两点”定位、“两地“两高”目标。

3.1 .2 强化规划、备好平台

在已完成高新区 $50 \mathrm{~km}^{2}$ 总体规划修编和产业规划编制的基础上，依托庆兰实业等，建设 高端汽车零部件产业基地; 以天齐锂业为龙头, 建设新能源材料产业基地; 与小米公司合作, 发展小米生态链产业园, 建设智能制造硬件基地。

\subsection{3 加大引领、提质提速}

加大引领, 围绕重点产业, 引进红岩方大、一汽富茂等高端汽车零部件项目 8 个, 金金金 新能源、昂佳科技等新能源材料项目 11 个, 壹壹光学、元铂科技等智能制造硬件项目 11 个, 顺安爆破、伊菲斯特等 27 个项目竣工投产，达产后可实现年产值 290 亿元以上。

\section{2 产业结构发展的短板}

当前, 铜梁仍属于欠发达地区, 发展不平衡不充分的问题较为突出, 生产结构和组织结 构不够合理、第三产业增长方式传统, 创新不够, 内部结构调整空间较大; 区域性生产过剩, 企业生产高能耗、高成本, 产业结构转型升级面临较大挑战; 传统的商业、服务模式占主导, 邮电、通讯、金融保险、信息、咨询等调节空间较大 ${ }^{[4]}$ 。

\section{3 铜梁区与周边区县产业布局的比较}

铜梁与周边区县的产业结构布局比较结果详见表 2。从表 2 分析出如下观点:

一是铜梁区现有的轨道交通制造产业、新能源新材料产业、大健康产业具有差异性。

二是铜梁区现有的汽车零部件产业、智能制造产业、生态农产品加工产业不具备差异性。

表2 铜梁区与周边区县产业结构布局比较表

\begin{tabular}{|c|c|c|c|c|c|c|}
\hline 地区 & \multicolumn{9}{|c|}{ 产业结构布局 } \\
\hline 大足 & 五金家居 & $\begin{array}{c}\text { 汽摩整车及零部 } \\
\text { 件 }\end{array}$ & 新兴产业 & 高端装备 & 文化旅游 \\
\hline 合川 & 港口物流业 & & 纺织服装业 & 装备制造 & 食品加工 & 一般加工、信息 \\
\hline 潼南 & 精细化工 & 电子信息 & 清洁能源 & 机械制造 & 农副产品加工 & 轻纺造纸、灯饰 \\
\hline 壁山 & & 汽车零部件 & 信息技术 & 智能装备 & 生命健康 \\
\hline 铜梁 & 轨道交通制造 & 汽车零部件 & 新能源新材料 & 智能制造 & 生态农产品加工 & 大健康产业 \\
\hline 比较结果 & 具备差异性 & 无差异性 & 具备差异性 & 无差异性 & 无差异性 & 具备差异性 \\
\hline
\end{tabular}


4. 对策

根据以上分析，基于创新驱动战略和优化产业结构思路，提出铜梁产业结构发展的对策。

\section{1 比较周边区县、采用差异化战略}

与铜梁区周边区县的产业布局进行比较，如表 2 所示，采用差异化战略发展策略，大力 发展与周边区县的发展产业具有差异性的产业，如轨道交通制造、新能源新材料和大健康产 业; 有条件发展与周边区县布局的产业具有相似性、雷同性的产业, 如汽车零部件、智能制 造及生态农产品加工产业等。

\section{2 充分发挥创新驱动战略}

运用创新驱动的思路和方法, 研讨铜梁产业结构发展的环境、机遇、资源等要素, 增强 科技成果转化能力，以自主创新提升产业整体技术水平。

\section{3 继续加强农业基础地位}

一是要提高农业综合生产能力，加强农田水利建设; 二是要提高农业智能化、机械化水 平，稳定发展粮食生产; 三是要优化农业产业布局，促进农业可持续发展 ${ }^{[4]}$ 。

\section{4 进一步发展现代服务业}

要努力提高现代服务业的比重, 如提质全域旅游; 要调整和优化服务业结构, 提高服务 业水平和层次，如繁荣商贸业态；要加快服务领域的改革步伐，如拓展专业服务。

\section{致谢}

本文为重庆市铜梁区社会科学规划重点项目《创新驱动视域下铜梁产业结构优化研究》 (skgh2019005)的阶段性成果之一。

\section{References}

[1] Chang-shun WU, Marketing[M]. Beijing: Economic Management Press. 2001.

[2] Yong-xiang ZUO, The government work report 2018 in Tongliang Chongqing Municipal People's Government [R] Tongliang district government official website.2018.1.20

[3] Yong-xiang ZUO, The government work report 2019 in Tongliang Chongqing Municipal People's Government [R] Tongliang district government official website.2019.2.19

[4] Yong ZHAO, The change and its characteristic of the industry structure in China[J]. Journal of Xuzhou Education College, pp. 12-13, 2001(03). 